\title{
Jan Polášek
}

News and Notices. In memoriam Professor Miloslav Hampl

Czechoslovak Mathematical Journal, Vol. 25 (1975), No. 1, 163-167

Persistent URL: http://dml.cz/dmlcz/101302

\section{Terms of use:}

(C) Institute of Mathematics AS CR, 1975

Institute of Mathematics of the Czech Academy of Sciences provides access to digitized documents strictly for personal use. Each copy of any part of this document must contain these Terms of use.

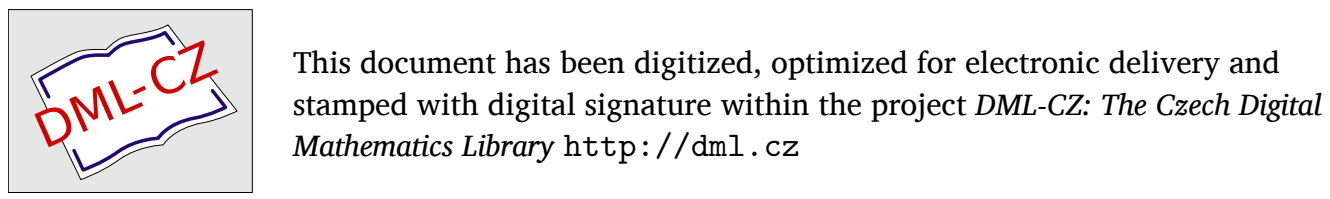


NEWS and NOTICES

\title{
IN MEMORIAM PROFESSOR MILOSLAV HAMPL
}

\author{
JAN PoLÁšEk, Praha
}

The doyen of Czechoslovak applied mathematicians Professor RNDr. MiLosLAV Hampl, Doctor of Science, corresponding member of the Czechoslovak Academy of Sciences, Klement Gottwald State Prize Winner, member of the Scientific Board of Mathematics of the Czechosilovak Academy of Sciences, awarded the distinction "For services rendered to science and mankind" of the Czechoslovak Academy of Sciences and Bernard Bolzano golden medal for the advancement of mathematical sciences, one of the founders of the Journal Aplikace matematiky (Applied mathematics) and a long-standing member of its Editorial Board, died on 20th January, 1974 after a long illness at the age of seventy-six.

Professor Miloslav Hampl was born on 10th August 1897 at Netolice in southern Bohemia. After taking his high-school diploma in 1915 at České Budějovice high school he entered Charles University in Prague where he studied mathematics and physics in the years 1915-1920. It was already during his studies when he disclosed his great talent, diligence and first of all his specific interest in applied mathematics. A year before completing his study he became Assistent Lecturer at the College of Mechanical and Electrotechnical Engineering in Prague, his appointment being propounded by Professor Nušl. When Professor Nušl retired, Hampl worked together with Professor Rádl and later with Professor Hruška. In 1922 he defended his thesis "Polarisation of boundary lines of total reflection", hence taking his RNDr. degree. During his stay at the University of Technology his interest in applications further developed. His desire to gain deeper insight into technical problems manifested itself in external studies of technology and resulted in passing the first public examination (corresponding approximately to B.Sc. degree) at the College of Mechanical Engineering. In 1930 he was appointed Reader (Dozent) at the College of Mechanical and Electrotechnical Engineering on the basis of his dissertation "Stress of hemispherical thick-walled vessel under hydrostatic pressure" which has a strongly applied character. The problem of stress of thick-walled vessel was solved by Hampl first by means of an infinite series involving Legendre functions. Later on he gave a more precise solution introducing hemispherical functions.

However, Professor Hampl did not cultivate his ideas of application of exact mathematical methods in technical sciences and industry just in the quiet university 
rooms but, which may be considered a characteristic feature of his, goes to the real technical and industrial practice. In 1930 he takes a job in the just established Mathematical Department of Škoda Works which was the first institution of this kind not only in our country but even abroad and which played a decisive role in the development of the Czechoslovak machine industry before the Second World War. Later on, Professor Hampl became head of this Mathematical Department. Nowadays, when mathematics is widely penetrating all branches of human effort, we can hardly even imagine all difficulties which had to be overcome by young Hampl, especially to show engineers and designers convincingly the advantages of mathematical solution of technical problems. The problems solved by himself which were published both in our and foreign journals not only excited admiration and appreciation of mathematicians but, first of all, gained confidence of engineers in reliability and usefulness of mathematical solution of problems which had been till then solved experimentally with immense difficulties, or considered unsolvable at all.

When the Czechoslovak industry was nationalized, Professor Hampl rebuilt the Mathematical Department into the Theoretical Department of State Research Institute of Thermotechnics (presently the Department of Applied Mathematics, State Research Institute for Machine Design). Under his guidance the department grew into an outstanding research centre for application of mathematics in engineering sciences and technology, well-known even abroads. Among other, the fact that nine research workers and one team from its ranks have been awarded the State Prize may serve an evidence of its successful work.

Besides his scientific work, Professor Hampl considered the education of young students and research workers to be of firstrate importance. Even if he spent most of his creative life time with industry and research institutes, he was all the time in close contact with universities and, as a doctoral adviser, educated a number of outstanding specialists who hold now important officies both in science and industry and continue to develop his ideas.

After his long successful work in technological and industrial research Professor Hampl came in 1964 to the Mathematical Institute of the Czechoslovak Academy of Sciences and, after two years, to Faculty of Mathematics and Physics, Charles University. Here he spent most of his time in educating new specialists mainly in applied mathematics and contributed to the development of the Centre of Numerical Mathematics of the Faculty. However, he continued to cooperate with the machine industry until his serious illness made it impossible for him to participate in scientific and educational activities.

The scientific activity of Professor Hampl may be characterized by one fundamental leading idea - to solve technical problems by means of exact mathematical methods and to bring the results obtained to the form directly applicable in practice. His 38 scientific papers and more than 300 research reports embrace several thematical domains. The above mentioned problems of thick- and thin-walled vessels form the first of them. Hampl's results from this field served also the starting point of the 
strength evaluation of the spherical gas-container in Prague - Palmovka. Also the investigation of stability of a wall of web girders was originated by practical needs. The solution given by Professor Hampl has been the most accurate of all known until now and is frequently quoted in literature. Another field of interest is represented by the problems of stress of a plate with holes with shrinkfitted pins. In a number of cases Hampl found explicit results directly applicable in practice. He payed much attention also to the problems of stress of circular plates and rotating disks. $\mathrm{He}$ investigated all important states of stress of circular plates with variable thickness. He suggested a general method of determination of stresses of a rotating disk in elastic and elasto-plastic state. All these papers unify high mathematical level with deep understanding for the needs of practice. For example, he does not stop at deducing relations for maximum stress in circular plates of variable thickness but analyses by means of his results the savings of material and determines from this point of view the optimal choice of thickness. Professor Hampl's scientific work as well as his educational activity at universities and in research contributed considerably to the high theoretical and scientific standard of Czechoslovak machine industry.

One of invaluable features of Professor Hampl was his ability of predicting which of the developing scientific fields could be of importance for engineering and technological sciences. This was why he gave the impulse to create the department for photoelastometry of Škoda Works which later contributed fundamentally to the development of photoelastometry in our country. The same forethought led him to carry through the department of mathematical statistics directed above all to the inspection of quality of production, the importance of which has been fully appraised only in the new system of control of production. His scientific work enabled him to appreciate fully the importance of numerical methods and computations as well as the enormous possibilities of the modern computation technique. The Computation Centre of the Ministry of Heavy Machine Industry at the State Research Institute for Machine Design, built up by Professor Hampl, was one of the first enterprieses of the kind and played an important role in introducing modern computer technique in our country. Professor Hampl's interest and effort in introducing modern computers led him to close active cooperation with the Research Institute of Mathematical Machines. He was for many years member of its Scientific Counsil and scientific editor of the Journal for Data Processing.

For his merits, Professor Hampl was awarded the Klement Gottwald State Prize in 1955 and in 1956 he was conferred the Doctor of Science degree. In 1962 he was elected corresponding member of the Czechoslovak Academy of Sciences and in 1963, his valuable educational activity which he always considered of outstanding importance was acknowledged by his appointment Professor of Applied Mathematics. For his contribution to the development of machine industry he was appointed honourable member of the State Research Institute for Machine Design in 1966 while a year latter he was elected honourable member of the Czechoslovak Society for Mechanics. The Czechoslovak Academy of Sciences appreciated his scientific 
work by the distinction "For services rendered to science and mankind" and last but not least, by the Bernard Bolzano golden medal for the advancement of mathematical sciences on the occasion of the 75th anniversary of his birthday.

Professor Hampl held important offices in a number of scientific institutions and committees mostly of considerable importance. He was member of the Scientific Board of Mathematics of the Czechoslovak Academy of Sciences, Committee for mathematics and Physics for Klement Gottwald State Prize, National committee for scientific qualification, National Committee of IUTAM. Furthermore he was member of scientific councils of several institutes, editorial boards of scientific journals and worked actively in several scientific societies in our country and abroad. In all his activities he always revealed his profound knowledge, organizing abilities and realistic view of the problems considered.

Professor Hampl was not only a great scientist but also an outstanding personality with deep interest in culture, popular for his delicate character, real interest in anybody's needs and readiness to help. Till his old age he was an active sportsman and, particularly, a great admirer of nature. The time which he spent in his beloved Rokycany region meant for him always an encouragement to his further work.

Professor Hampl's fruitful life was fully devoted to science and to the service to mankind. Our science, industry, universities as well as our journal have lost a distinguished specialist and all who knew him personally a true friend, a willing advisor and a man of honour, who will be always remembered with admiration and gratitude.

\section{LIST OF PUBLICATIONS}

[1] Potierova relace v př́ípadě totální reflexe na krystalech dvojlomných, 1922, Čs. akad. věd a umění. Also in German, Zentralblatt für Mineralogie, 1924, 520-529.

[2] Polarisace hraničních čar totální reflexe I., Čs. akad. věd a umění, 1924.

[3] Polarisace hraničních čar totální reflexe II., Čs. akad. věd a umění, 1924.

[4] Přibližné řešení problému kmitání s odporem úměrným čtverci rychlosti, Tech. obzor 1926, p. 278.

[5] Poznámka k těžné řetězovce, JČMF 1927, p. 16.

[6] O nomogramech, Report of Military Institute of Aviation, 1928.

[7] Namáhání polokulové silnostěnné nádoby hydrostatickým tlakem, Věd. spisy Mas. akad. práce, 1929, No. 48 (Thesis).

[8] Über die hemisphärische Funktion, Wiener Monatsheft f. Math. u. Phys., 1930, 215-222.

[9] Fotoelasticimetrie, Letectví 1929.

[10] Poznámky k teorii pružin, Stroj. obzor 1930.

[11] Deformation und Spannungszustand der achsensymetrisch belasteten dicken Kugelschale. Lecture at the Congress of Mathematicians from Slavonic countries 1934, Prague.

[12] Zur Berechnung von Schwingungen mit quadratischer Dämpfung, Ing. Archiv 1935, p. 213.

[13] Ein Beitrag zur Stabilität des horizontal ausgesteiften Stegbleches, Der Stahlbau, No. 2, 3, 1937.

[14] Průhyb a namáhání kulového dna zatiženého radiálním tlakem, Čs. akad. věd a umění, 1937, V. 47, No. 20.

[15] Stress of Circular Plate of Linearly Variable Thickness, Škoda News, 1938. Also in Czech 
and German, Technické zprávy Škodových závodů, 1939, Škoda Mitteilungen 1939, respectively.

[16] Tvar vertikálně zatíženého lana, Techn. obzor 1938, No. 6.

[17] Namáhání kulového víka osamělou silou, Technické zprávy Škodových závodů 1944. Also in Gcrman, Škoda Mitteilungen 1940, 56-61.

[18] Das Spannungsproblem der achsensymetrisch belasteten dicken Kugelschale, Bautechnik (Appendix Stahlbau) 1940, 96-100.

[19] Výpočet úkolového času, Technická zpráva Škodových závodů 1940, 109-119. Also in German, Škoda Mitteilungen 1941, 1-12.

[20] Moment tuhosti v kroucení u mezikruhové výseče, Stroj. obzor 1941, 216-220. Also in English, Engeneering Digest, 1946, and in German, Škoda Mitteilungen, 1943, 97.

[21] Reakce a namáhání spojitého nosníku, Techn. zpravodaj Škodových závodů, 1942. Also in German, Škoda Mitteilungen, 1942, 33-52.

[22] Poznámky k přirozené součtové řadě algebraické, Elektrotechnický obzor 1943, p. 187.

[23] Graphishes Verfahren zur Ermittlung der Erstarrungsgeschwindigkeit. Král. uč. Společnost nauk 1943 (With dr. Vodička).

[24] Součet rozvojů podle ortogonálních funkcí v techn. problémech, Čs. akad, věd a umění, 1945.

[25] Napjatost kulové skořepiny v okolí podpěry, Techn. obzor 1950, No. 8.

[26] Napjatost desky s řadou zalisovaných kruhových čepủ, Techn. zprávy Čs. stroj. a kovoděl. průmyslu 1951, No. 9.

[27] Rotující kotouč v plastickém stavu, Stroj. sborník 1952, V. 1, 87-114.

[28] Součet speciálních nekonečných řad, Elektrotechnický obzor 1952, No. 12, 697-8.

[29] Napjatost desky s dvěma zalisovanými kruhovými čepy, Čas. pro pěst. mat., 1954, 65-75.

[30] Stress in an infinite plane with a) two b) an infinite row of shrinkfitted circular pins. International Congress of Applied Mechanics, Brussel 1951.

[31] Kruhové desky s proměnlivou tlouštkou namáhané přetlakem, Stroj. sborník V. 9, 1954, $39-72$.

[32] Namáhání rotujícího kotouče proměnlivé tlouštky, Stroj. sborník V. 9, 1954, 74-96.

[33] Napjatost a deformace membránových kompensátorů, Strojírenství 1955, No. 10.

[34] Das Spannungsproblem für dicke offene Schalen. Physikalische Verhandlungen, sv. 8, 1957, řada 3, p. 65 (with ing. Valenta). Also in German, ZAMM, 1957 Bd. 27.

[35] Anuloidová skořepina a vlnové kompensátory pro potrubí, ČSAV, 1958, (Book).

[36] Spannungsverlauf in einer rotierenden Scheibe mit veränderlicher Dicke, ZAMM, No. 7/8, 1958.

[37] Řešení algebraické rovnice čtvrtého stupně, Aplikace matematiky 1949, No. 4.

[38] Aplikovaná matematika v prvním padesátiletí naši republiky, Aplikace matematiky 1968.

\section{STATE PRIZE WINNER FOR MATHEMATICS MILOŠ ZLÁMAL}

On 1st May 1974, President of the Czechoslovak Socialist Republic awarded Professor RNDr. Miloš ZlámaL DrSc., head of the Computer Laboratory of the College of Mechanical Engineering, Technical University in Brno, the Klement Gottwald State Prize for the creation and development of the mathematical theory of finite elements and its application in technical practice. We use this opportunity to acquaint our readers with the personality and scientific activities of M. Zlámal.

The life as well as the scientific career of Professor Zlámal is closely linked together with the city of Brno. He was born 1924 in Zborovice near Kroměřǐž. He attended secondary school at Brno where he passed his school-leaving examination in 1944. After the liberation of Czechoslovakia he studied mathematics and physics at the Faculty of Science in Brno in the years 